\title{
The Memoirs of Cola Nicea: A Case-Study on the Discursive Identity Construction of the Aromanian Armatoles in Early $20^{\text {th }}$ Century Macedonia
}

\author{
„Wspomnienia” Coli Nicei: \\ Studium przypadku o budowie tożsamości dyskursywnej \\ arumuńskich „armatole" w Macedonii na poczq̨tku XX wieku
}

\section{STRESZCZENIE}

Artykuł rozpoczyna się od ogólnego omówienia Wspomień Coli Nicei - dokumentu, który został poddany analizie z wykorzystaniem metod zaczerpniętych z krytycznej analizy dyskursu. W pracy wyjaśniono etnonimy używane przez Niceę w jego opowieści, co prowokuje do dyskusji o tożsamościach macedońsko-słowiańskiej i macedońsko-arumuńskiej na początku XX w. W dalszej kolejności omówiono formy i powody współpracy między arumuńskimi armatoles a comitadji Tajnej Macedońskiej Organizacji Rewolucyjnej w Adrianopolu, tak jak zostało to ukazane w tekście Nicei. Informacje zawarte w tym źródle prowadzą do konkluzji, że filorumuński dyskurs okazał się nieprzydatny w obliczu zaostrzenia kryzysu macedońskiego, a Arumuni, miłośnicy Rumunii, przyjęli drugi dyskurs, przez twórcze połączenie go z programem politycznym Tajnej Macedońskiej Organizacji Rewolucyjnej w Adrianopolu. Artykuł odnosi się również do rozmaitych tekstowych i metatekstowych narzędzi, które odgrywają rolę w iteracji pozycji podmiotu arumuńskich armatole Coli Nicei.

Słowa kluczowe: tożsamość, dyskurs, „pozycja podmiotu” (subject-position)

\section{ABOUT THE DOCUMENT AND ITS AUTHOR}

Of all the Aromanian armatole captains fighting in Macedonia during the first decade of the $20^{\text {th }}$ century, only four had a high-school degree: Mihail Handuri, Gheorghe Mucitani, Traian Cucuda and Cola Nicea. Of 
these four, only Nicea has left us a written account of the events that transpired in early $20^{\text {th }}$ century Macedonia. His Memoirs are the only first-hand account of the life, thoughts and deeds of an Aromanian armatole that we possess.

Cola Nicea was born in 1886, in the town of Veria. After the First World War, he moved to the town of Bazargic, in the Caliacra county (today part of North-East Bulgaria, it was one of the two counties annexed by Romania after the Second Balkan War). Many of his comrades in arms from the days of Macedonian crisis also settled there with him. When in 1940 Romania returned Durostor and Caliacra counties to Bulgaria, Cola Nicea moved again, this time to Constanţa, in Romanian Dobrudja.

Nicea wrote his Memoirs in his old age, basing his written account on his memories and some old, scattered notes. In spite of a failed publication attempt in the 1970s, the memoirs remained unpublished until after the fall of the Romanian communist regime (December 1989).

During the 1990s fragments of the memoirs were published in the "Deşteptarea" magazine, edited by Mr. Hristu Cândroveanu. Finally, the complete, original version of Cola Nicea's Memoirs was printed in the December 2001 issue of "Scara" magazine, year V, "Treapta a şaptea" publishing, Bucharest.

The copy of Cola Nicea's memoirs that we are using for our analysis is a digitalized version of this first (and until now, the only) complete printed edition. It has been downloaded from the www.proiectavdhela. com website, on 23 May 2013; the complete text continues to be available for free download on the aforementioned website.

As to the document's content, it makes the title (Memoirs) seem somewhat misleading, for this is not, in its entirety, a first-hand account.

In effect, The Memoirs of Cola Nicea can be subdivided into three constituent parts, in accordance with the author's degree of proximity to the narrated events:

A. A first-hand account of the author's experiences, while acting as an Aromanian armatole during the Macedonian crisis of the early $20^{\text {th }}$ century. This is the most substantial part of the document, covering a time frame spanning roughly from the aftermath of the Ilinden Rebellion (1903) to the Young Turk Revolution (1908).

B. A second-hand account of synchronous events happening elsewhere in historical Macedonia - namely, in Meglenia (just north of the Chalcidic peninsula, in modern-day Greece).

C. A succinct overview of the aftermath of the Balkan wars, with particular emphasis on the wars' consequences for Macedonian Aromanians. 
Our analysis is chiefly concerned with Cola Nicea's first-hand account (A), this being the part most likely to offer fresh insights into aspects of the Macedonian crisis.

For the purposes of the present analysis we shall be using an interdisciplinary methodological approach called Critical Discourse Analysis (or CDA, for short). CDA is a research field encompassing a set of analytical approaches which combine methods and concepts borrowed, broadly speaking, from two disciplinary fields: language studies (applied linguistics, philosophy of language, etc.) and social research in its broadest sense (sociology, anthropology, political science, history, etc.).

For the sake of brevity, we would rather not encumber the reader with a lengthy description of CDA methodology. Suffice it to say that we are basing our analytical outlook chiefly on Norman Fairclough's seminal book, Language and Power ${ }^{1}$. Our methodological approach shall become gradually apparent in the process of text analysis itself.

\section{ON COLA NICEA'S USE OF ETHNONYMS}

Ethnonyms are an important component of all discourse of national identity; or, as Patrick Sériot, puts it, "The nation is not a natural object, but a category, which exists first and foremost in the name that a community gives itself, or that others assign to it from the outside. [...] the stake of nomination is the expression of being" 2 .

In short, ethnonyms are an expression of a community's core identity. Which is why before we can proceed to discourse analysis proper, we have to clarify the meaning of the ethnonyms used by Cola Nicea through-

${ }^{1}$ To be more specific we are using the second (latest) edition of Fairlcough's book: N. Fairclough, Language and Power, $2^{\text {nd }}$ edition, London, New York 2001; in the preparation of this paper we have also used a plethora of other works on CDA, and on discourse analysis in general: see, in particular N. Fairclough, Critical Discourse Analysis, in: The Routledge Handbook of Discourse Analysis, eds. J. P. Gee, M. Handford, London and New York 2012; H. G. Widdowson, Discourse Analysis, Oxford 2007; R. Wodak, The Discourse of Politics in Action: Politics as Usual, Palgrave Macmillan 2011; D. Howarth, Y. Stavrakakis, Introducing Discourse Theory and Political Analysis, in: Discourse Theory and Political Analysis: Identities, Hegemonies and Social Change, eds. D. Howarth, A. J. Norval, Y. Stavrakakis, Manchester and New York 2000.

${ }^{2}$ My translation. The original quote in French: "La nation n'est pas un objet naturel, mais une catégorie, qui existe avant tout dans le nom qu'une communauté se donne à ellemême ou que d'autres lui donnent de l'extérieur. [...] Un ethnonyme n'est pas le reflet direct d'une "chose», mais un objet de discours. Dans cette perspective la lutte pour le nom a exactement la même importance à l'Ouest qu'à l'Est, car l'enjeu de la nomination est l'expression de l'être" see P. Sériot, Ethnos et demos: la construction discursive de l'identité collective, "Langage et société" 1997, 79: "Analyse discursive et engagement: autour de l'Europe de l'Est", pp. 44-45. 
out his account. Proceeding otherwise would not only prevent us from correctly identifying the main actors of the narrated events, but it would, in the long run, expose us to the risk of misapprehending how the actors perceive themselves and how they relate to each other.

This is due to the fact that the ethnonyms employed by Cola Nicea are rather problematic, as we shall see. They are basically used to designate the national groupings vying for control of Macedonia during the first decade of the $20^{\text {th }}$ century. These groupings, as reflected in Nicea's account, are: the Greeks, the Bulgarians, and the Romanians ${ }^{3}$.

The first ethnonym is unproblematic, for it obviously refers to the national Greek involvement in the Macedonian crisis: Greek agents, Greek interests, etc. A distinction is even made, within the Greek "camp", between actual Greeks, and Bulgarian and Romanian so-called "grecomaniacs"4.

The author's use of the word "Bulgarian" appears, however, much more troublesome. It would, at first glance, seem to be used as a blanketterm for all Macedonian Slavs and the term's obvious potential reference to actual (un-Macedonian) Bulgarians further complicates matters.

Furthermore, when using the ethnonym "Bulgarian", there is no distinction made between $\mathrm{TMORO}^{5}$ and supremist ${ }^{6}$ agents, which creates problems from the perspective of the modern historian.

${ }^{3}$ No mention whatsoever is made of the Serbs.

4 "grecomaniac" (grecoman in the original Romanian) is a term used by the Romanian propaganda of the time to describe Aromanian activists affiliated with, and actively supporting, the Greek national agenda in the Balkans.

5 This acronym designates the Macedonian revolutionary organization founded in 1893 and also commonly referred to as the Internal Organization. According to the Macedonian scholar Ivan Katardžiev, the Organization originally bore the official name "Bulgarian Macedo-Adrianopolitan Revolutionary Committee" (BMORK), whilst by 1896, it had changed its name to "Secret Macedo-Adrianopolitan Revolutionary Organization" (TMORO). We shall opt for the latter designation since it seems to better reflect the longterm orientation of the institution; see I. Katardžiev, Nekoi prašanja za ustavite i pravilnicite na VMRO do Ilindenskoto vostanie, "Glasnik ná Institutot za nacionálna is-torija" 1961, 1, pp. 156, 162, quoted in: T. Marinov, We, the Macedonians: The Paths of Macedonian Supra-Nationalism (1878-1912), in: We, the People: Politics of National Peculiarity in South-Eastern Europe, ed. D. Mishkova, Budapest 2009, http://www.ceeol.com/aspx/getdocument.aspx?logid=5\&id= 5db4b51192bd4f7a85e7699046929d54 [accessed on: 13 November 2015].

${ }^{6}$ The so-called "supremes" were a group of associations of the Macedonian diaspora in Bulgaria, which merged in 1895 into the Sofia-based "Macedonian Committee", later renamed "Supreme Macedonian Committee", and "Supreme Macedono-Adrianopolitan Committee". This external organization, also known to Macedonian historiography as the "supremes" (vrhovisti), initially collaborated with the TMORO (also known as the "internals", or the "centralists'" - centralisti); however, the two organizations gradually grew apart as the "supremes" gravitated towards Bulgarian unionism, thus antagonizing the "centralists" Macedonian autonomist/independentist leanings; see the study of T. Marinov, op. cit., pp. 9-10. 
However, things are not as dire as they appear at first glance. Wherever the collocations ${ }^{7}$ "Bulgarian tchetas" and "Bulgarian villages" appear, they are either directly or implicitly associated with the fight for Macedonian autonomy. Thus, it is clear that, for the most part, the term "Bulgarian" is used, alone or in its various collocations, to refer to the TMORO agents and the TMORO activity - an organization which advocates Macedonian autonomy, as opposed to Bulgarian unionism ${ }^{8}$.

Bulgarian unionism is actually only mentioned once in the first-hand portion of our document; this remark occurs in the context of Boris Sarafov's visit to Macedonia in the winter of 1906-1907. "The inspector-general of the Bulgarian tchetas" (as Sarafov is described) is reported to have said during a private conversation: "You know very well that our organization also killed Tachev ${ }^{9}$, while he was a prime minister of Bulgaria, because Tachev had spoken in favor of Macedonia's incorporation into the Bulgarian state, and against its independence"10.

As Sarafov is, since 1902, a prominent leader of the TMORO, his reported visit to the "Bulgarian" tchetas (in the winter of 1906-1907) clearly indicates the TMORO's allegiance to the said "Bulgarian" tchetas. Furthermore, Sarafov's reported statement draws a clear dividing line between the Bulgarian unionists and Bulgarian autonomists, with our "Bulgarian" tchetas clearly belonging to the latter category.

However, part of the confusion caused by Nicea's indiscriminate use of the term "Bulgarian" derives from applying our own contemporary conceptions of Balkan nationality to realities over a century old. The

${ }^{7}$ Collocation means co-occurrence of two or more words in a text. If a group of words occurs together in a text very frequently the collocation in question may have particular ideological significance or be otherwise central to a particular discourse; collocation is drawn upon particularly in quantitative (corpus-oriented) approaches to discourse analysis; see H. G. Widdowson, op. cit., pp. 79-80, for more on collocation.

${ }^{8}$ Although certain members of the TMORO occasionally had close dealings with Bulgarian agents and despite the fact that the organization was initially highly dependent upon Bulgarian backing, it is here that the first steps towards a Macedonian national idea were taken. The aim of the TMORO was the preparation of a general Macedonian antiOttoman uprising. Its goal: Macedonian autonomy, under the slogan "Macedonia for the Macedonians!"; see B. Jelavich, Istoria Balcanilor, vol. 2, Iaşi 2000, p. 91.

${ }^{9}$ We have been unable to identify who Tatchev was; he does not seem to figure among Bulgaria's prime-ministers of the time; perhaps Nicea is mistaken about Tatchev's exact political position in the Bulgarian government.

${ }^{10}$ C. Nicea, Memorii [Memoirs], p. 23 (my translation from Romanian); document originally published in Scara - Revistă de oceanografie ortodoxă, Bucureşti: Treapta 7, 2001; digitized by Predania Publishing House, http://www.proiectavdhela.ro/pdf/cola_nicea_memoriile. pdf [accessed on: 12 November 2015]. 
Macedonian researcher Tchavdar Marinov underscores the fact that the TMORO's ideology was not as clear-cut anti-Bulgarian as the conventional Macedonian historiography would have us believe. In fact, it seems that on some occasions, the TMORO members affirmed themselves as ethnically and even culturally Bulgarian, while simultaneously advocating the need for independent Macedonian statehood ${ }^{11}$.

This points to the distinct possibility that the ethnonym "Bulgarian" was actually being used by the TMORO members themselves for self-designation, in their interactions with each other, and with other nationalities. This would certainly explain its profuse and indiscriminate use by Cola Nicea.

What about the ethnonym 'Macedonian' then, you may ask. We should specify that the word "Macedonia" was invested, at the time, with a purely geographical significance: it carried no political, ethnic or national meaning ${ }^{12}$. Therefore, a Macedonian was simply somebody from the geographical region of Macedonia.

Cola Nicea himself, on one occasion, makes use of the word in its expressly geographical sense; a prisoner of the Aromanian armatoles begs for his life, in the eve of his execution:

[...] - I am a Bulgarian from Neagushte. I am a school inspector at the Greek language schools. Minga started crying, he wailed and begged us to let him go as he was not Cretan, but Macedonian ${ }^{13}$.

In this fragment, the term "Macedonian" is manifestly used as a designator of geographical origin: the speaker professes to be Macedonian,

${ }^{11}$ See Političeski separatizâm, "Pravo", June 7, 1902, quoted in T. Marinov, op. cit., pp. 12-13; the newspaper "Pravo" ["The Right"], edited by the Macedonian activists Nikola Naumov and Toma Karajovov, was the unofficial press outlet of the TMORO.

${ }^{12}$ In the time-frame which concerns the present paper (late $19^{\text {th }}$ century - early $20^{\text {th }}$ century), the term "Macedonia" referred to a rather vaguely delimited geographical entity, which, broadly speaking, bordered on Mount Olympus, the Pindus Mountains and the Aegean to the south, the Šar Mountains (Šar Planina) to the north, the Rhodope Mountains to the east and Lake Ohrid to the west; the modern (19 $19^{\text {th }}$ century) use of the term "Macedonia" originated with western-European geographers, its most direct political reference being Philip II's ancient kingdom of Macedonia. In other words, the modern use of the term was purely geographical since there was no contemporary political or administrative entity corresponding to it. Certainly, the name meant nothing from the point of view of the Ottoman administration: what the westerners called Macedonia in fact spanned over the Ottoman vilayets of Selanik and Bitolia, the sandjak of Servia, and parts of the vilayet of Kossovo; see G. Castellan, Histoire des Balkans XIVe-XXe siècle, Fayard 1991, p. 350.

${ }^{13}$ C. Nicea, op. cit., p. 12 (my translation from Romanian). 
as opposed to Cretan (also a geographical designator); he concomitantly affirms himself as being of Bulgarian ethnicity.

Interestingly, however, that is not to say that the term "Macedonian" is never used with a national corollary in Nicea's narrative. During Boris Sarafov's reported visit of the Bulgarian tchetas' encampment, the TMORO leader on one occasion refers to the "Macedonian people". However, this collocation is used neither in an ethnic, nor in a strictly ethno-national sense, but in the supra-national, multi-ethnic interpretation that is a salient characteristic of the TMORO's discourse ${ }^{14}$ :

"Our organization condemns to death all those who betray the Macedonian people, regardless of the ethnic groups which constitute this people"15, Sarafov is reported to have said.

At the end of the very same paragraph, Cola Nicea uses the collocation again, this time on his own account (that is to say, he uses it himself, rather than while quoting someone else's words); while evoking the memory of a certain Ivanciu Mihailov, Nicea characterizes this person as "the great fighter for the justice of the Macedonian people"16.

This second use of the collocation "Macedonian people", which Nicea crucially now appropriates as his own, is by no means accidental; it suggests that the notion of a multi-ethnic, yet cohesive, Macedonian people is a key feature of Aromanian armatole discourse. We shall be returning to this subject in a moment for it invites further development.

For now, however, let us direct our attention back to the issue of ethnonyms. What can we say about the use of the ethnonym "Romanian" in Nicea's text? Well, first of all, it is pervasive: whenever he refers to his own people (the Aromanians), Nicea uses the term "Romanian", either isolated or in several recurring collocations: "Romanian culture", "Romanian village", "Romanian community", etc. Crucially, the ethnonym "Aromanian" is not even once used throughout the whole text! This points to an implicit assumption of a complete synonymy between the terms "Romanian", and "Aromanian"17. This presupposition alone places our text squarely within the confines of romanophile (pro-Romanian) discourse.

14 The official statutes of the TMORO granted the right of membership to any "Macedonian or Adrianopolitan", while calling for the unification of all "unsatisfied elements", their "nationality" (narodnost) notwithstanding; see T. Marinov, op. cit., pp. 8-9.

${ }^{15}$ C. Nicea, op. cit., p. 22 (my translation from Romanian).

${ }^{16}$ Ibidem, p. 23.

${ }^{17}$ To the point where Nicea almost never feels the need to draw a distinction between Romanians from Romania and Aromanians from Macedonia; we say almost because he does, on one single occasion, use the collocation "Macedonian Romanian". 
Romanian discourse with respect to Macedonia is, however, exclusively cultural in nature; in no way does it promote armed rebellion ${ }^{18}$; in fact, King Carol I of Romania expressly forbade the formation of Aromanian armed detachments ${ }^{19}$.

But if Cola Nicea and his fellow Aromanian armatoles profess themselves to be Romanians, placing themselves within the romanophile identity discourse, would it not follow that their allegiance lies with the Romanian government? Why then are they going against Romania's express commands and taking up arms? And, more importantly, how do they justify taking such radical action? What cause do they profess to be fighting for?

In attempting to answer these questions, we shall begin by inquiring into the armatoles' close collaboration with the Slav insurgents of the TMORO.

AROMANIAN ARMATOLES COLLABORATING WITH THE TMORO: HOW AND WHY?

Let us begin by saying that Cola Nicea's Memoirs provide detailed insight into the modes and degrees of collaboration between the Aromanian armatoles and the TMORO comitadjis.

The fact concerning this close collaboration, as well as its main object, is brought to the fore in the very opening paragraph of the Memoirs:

Although almost all the men were arrested for the repression of the insurrection in Macedonia (1902-1903), Bulgarians and Romanians who had fought for Macedonian autonomy, several tchetas of combatants were formed, that struggled against the Turkish imperial armies. [...] The Turkish government [...] agreed with the Greek government that the latter should send Greek bands, with the purpose of destroying the Bulgaro-Romanian tchetas, which were acting jointly for the achievement of Macedonian autonomy ${ }^{20}$.

Let us break down the wealth of information that this single paragraph provides about the collaboration of Aromanian armatoles with Slav comitadjis.

We are told that "Bulgarians and Romanians" (i.e. Macedo-Slavs and Aromanians) had fought side by side during the Ilinden Rebellion; we are then told that joint (that is, ethnically mixed!) "Bulgaro-Romanian tchetas" continued fighting against the Turkish and Greek forces, in the aftermath of Ilinden's failure. We are informed that the purpose of the fighting is the achievement of Macedonian autonomy. And covert cooperation between the Ottomans and the Greek government is alluded to.

${ }^{18}$ N. Trifon, Les Aroumains, un peuple qui s'en va, La Bussière 2005, p. 244.

${ }^{19}$ M. D. Peyfuss, Aromânii în era nationalismelor balcanice, in: Aromânii: istorie, limbă, destin, ed. N. Djuvara, Bucureşti 2012, p. 180; N. Trifon, op. cit., p. 218.

${ }^{20}$ C. Nicea, op. cit., p. 4 (my translation from Romanian, my bold letters). 
All of these initial pieces of information are confirmed and reinforced throughout Nicea's account. It becomes apparent that, in smaller-scale actions, the Aromanian tchetas were acting independently; while in the case of large-scale endeavors, they merged with Macedo-Slav tchetas, acting together for the achievement of their common goals.

Nicea recounts how Gheorghe Mucitani, an Aromanian who was also "a seasoned combatant in the revolutionary committee for Macedonian autonomy" (the reference to the TMORO is obvious), organized the Aromanian bands according to the TMORO's principles, each band of armatoles being assigned a captain (voievod) and a district wherein to conduct its activity ${ }^{21}$.

The closeness of the TMORO - Aromanian collaboration could not be more obvious.

But what did the Aromanian armatoles think of this collaboration? We can find clues in Nicea's alternating, inclusive and exclusive, use of the second person plural definite pronoun ('we').

In Fairclough's approach to discourse analysis, it is emphasized that the use of this pronominal form, in order to implicitly include or implicitly exclude certain parties, sheds light upon the relational aspect of text analysis: on how relationships between participants are structured within a discourse ${ }^{22}$.

In Nicea's text, we encounter predominant use of exclusive "we" (as in "we", the Aromanian armatoles, and "them", the Slav comitadjis); however, inclusive "we" (as in "we", the Aromanians and Macedo-Slavs) is also used, particularly when the author recounts larger-scale actions, where Aromanian and Macedo-Slav tchetas are merged into larger, unitary groups.

This use of the second-person plural definite pronoun tells us two things: firstly, the Aromanians maintain their sense of identity and ethnic individuality throughout their collaboration with the TMORO (as shown by the predominant use of exclusive "we"); secondly, a sense of fellowship exists between the Aromanian armatoles and their Macedo-Slav collaborators, and this sense is given by commonality of purpose (whenever the two ethnic groups work closely together as one unit, inclusive "we" is used).

Cola Nicea's narrative style is curt and to the point, emphasizing the facts over subjective impression or emotions. However, on the few occasions where he talks about Slav comrades falling in battle, feelings of

${ }^{21}$ Ibidem, p. 5 (my translation from Romanian).

${ }^{22}$ See N. Fairclough, Language and Power, p. 106. 
brotherhood and respect emerge, confirming our hypothesis of an authentic sense of fellowship binding together the Aromanian armatole and Slav comitadji:

[...] we had to fight the soldiers [...]. Three soldiers fell dead, and we lost a dear comrade, namely the Bulgarian Mihalceto $^{23}$.

Another example:

During that clash Vani Manafi (i.e. the captain of a Slav tcheta), fearless combatant for Macedonian autonomy, fell heroically $[\ldots]^{24}$.

We have thus far addressed the question of how the Aromanian armatoles related to and collaborated with the TMORO comitadjis. However, we still have to understand why the armatoles were collaborating with the TMORO in the first place: why would the Aromanians be interested in achieving Macedonian autonomy?

At this juncture, it may prove necessary to elaborate on Romania's position vis-à-vis the Ilinden Rebellion, and towards the Macedonian crisis in general. We already know that the Romanian government had forbidden the Aromanians to take up arms in the Ilinden Rebellion. This provision is, in fact, part of the larger trend in Romanian foreign policy concerning the Balkans: at the end of the $19^{\text {th }}$ - beginning of the $20^{\text {th }}$ century, Romania is in fact conducting a pro-Ottoman foreign policy; behind this orientation lie several motivations.

First of all, Romania fears that any of the Balkan states expanding into Ottoman territory would cause a regional power imbalance, which, if not managed properly, could prove detrimental to Romanian interests in the region ${ }^{25}$; secondly, Romania is aware of the danger that any of the aggressive Balkan nationalisms would pose to Aromanian cultural survival, in the eventuality of Macedonia's annexation; thirdly, though the Aromanian community had always thrived in the a-national Ottoman millet system, that system was quickly breaking down in Macedonia; it was, therefore, imperative to secure an official Ottoman recognition of the Aromanians' status as a distinct ethnic and cultural community (lest they be assimilated by the other, officially recognized nationalities).

${ }^{23}$ C. Nicea, op. cit., p. 20 (my translation from Romanian).

${ }^{24}$ Ibidem, p. 20.

${ }^{25}$ I. Nistor, "Problema aromână" în raporturile României cu statele balcanice (1903-1913), Iaşi 2009, p. 68. 
For all these reasons, Romania opts to collaborate with the Ottoman Empire in maintaining the status quo in "European Turkey"26. On at least one count, the Romanian government even takes direct action against the Ilinden insurgents' collaborators, north of the Danube ${ }^{27}$.

All this amounts to one surprising conclusion: the Aromanian armatoles fighting in Macedonia (in close collaboration with the Macedo-Slav insurgents, no less!) are acting in direct opposition to Romania's official Balkan foreign policy!

Which bakes the question: how does one reconcile being a Romanophile Aromanian with acting in opposition to official Romanian state policy?

We shall begin addressing this question by looking at the frequency of the collocation "Macedonian autonomy" in Cola Nicea's Memoirs. This collocation, together with its variant, "autonomous Macedonia", occurs thirteen times in Nicea's text. It is, in fact, the single most frequently used pairing of words of the entire text.

Its high frequency of occurrence indicates that Macedonian autonomy holds an important spot in Aromanian armatole discourse. This is a concept totally alien to the philoromanian discourse; not so, however, in the case of the TMORO discourse, to which the concept of Macedonian autonomy is positively central.

We are now beginning to see that the ideological basis behind the Aromanian armatoles' actions is a composite one. For, although philoromanian discourse allows no room for freedom-fighter or militant partisan subject positions, the TMORO discourse does provide for such positioning of subjects.

This entire discussion on the nature and ideological basis of armatole discourse would remain highly speculative, had not Cola Nicea found a most ingenious way to showcase exactly who the Aromanian armatoles were and what they stood for.

In one recounted episode, Nicea's band of armatoles manages to capture Telos Agras, one of the leaders of the rival Greek movement. Nicea takes this opportunity to stage a dialogue between Agras and Gheorghe Mucitani, the leader of the Aromanian tcheta. We do not know if such a dialogue ever really occurred, and if it did, we certainly should not take

${ }^{26}$ This pro-Ottoman policy paid off at least in one respect: in 1905 the Sultan issued an iradé granting the Aromanians a recognition as a distinct nationality within the Empire and thus officially bestowing upon them the right to use their native language in school and in church; see I. Nistor, op. cit., pp. 97-109.

${ }^{27}$ Ibidem, p. 54. 
Nicea at his word concerning its contents ${ }^{28}$. However, the issues of event accuracy and narrator creditability are beside the point. What matters here is that Nicea uses this reported dialogue to expound the basic ideological features of Aromanian armatole discourse, as well as to "pencil in" the main elements of the Aromanian armatole subject position.

In what follows we shall give an ample, though selective, quote of the reported dialogue between Agras and Mucitani to be used as a basis for subsequent discussion:

The questions were asked by Gheorghe Mucitani:

- What is your name? Your real name? [...]

- My name is Kostas Agapinos. I took the pseudonym when I became the leader of the antart forces.

- What does Telos Agras mean?

- Telos means the perfect one, the flawless, but it also means the far away one, the distant one, the one not among us. Agras means the feral one, the fierce one, the untamed one.

- Where are you from?

- I hail from Crete. I graduated from the Athens military school, and in the Greek army I hold the rank of lohagos (captain).

$[\ldots]$

- Do you know who rules Macedonia?

- The Turks.

- Then why do you not fight the Turks? What do you have against the poor Romanians and Bulgarians, who are Christian just as you?

- We resolved we had to get the (demographical) majority by Hellenizing the Bulgarians, the Romanians and the Albanians.

- I don't think you'll succeed. Among those peoples, national consciousness has awakened. They fight for Macedonian autonomy. We want to create a Switzerland of the Balkans, where all the inhabiting peoples, Greeks, Bulgarians, Romanians and Albanians can enjoy equal rights. Autonomy is the only equitable solution. Only the Greeks, who are chauvinistic, arrogant, snobbish, even utopian, oppose this.

$[\ldots]$

(Mucitani:)

- You lack chivalry. In the winter of 1906-1907, at Balta Ianița, as the Turks were attacking us, you were also striking, dishonestly, from the back.

- That is true, for we want to destroy all that is orthodox and doesn't nurture Greek sentiments. Orthodoxy is a Greek church and those who profess orthodoxy must feel accordingly.

${ }^{28}$ At this juncture we should point out that according to Greek historiography Agras was not captured and executed by the Aromanian armatoles (as Nicea claims), but by the Bulgarian comitadji band led by one Zlatan; see D. Dakin, The Greek Struggle in Macedonia 1897-1913, Thessaloniki 1966. 


\section{$[\ldots]$}

(here there is a portion where Mucitani and Agras entertain a brief scientific/pseudo-scientific debate, trading conflicting academic arguments mobilized in their respective national ideologies. This is uninteresting for our purposes.)

$[\ldots]$

(Mucitani:)

It is true, Romanian, Bulgarian and Albanian national consciousness is not yet fully formed, this is why many of them become grecomaniacs and fight for a cause alien to their people.

- That is precisely why we are in a hurry ourselves and seek to nip in the bud the formation of national consciousness in the alien peoples.

- National consciousness has begun to awaken. We are many and you won't be able to kill us all. We bear the Turkish yoke. We want to shake it off, by proclaiming Macedonian autonomy, forming a multi-national state, where even the Greek population of Macedonia is to be part of this state. [...] We hold ourselves to be the descendants of Macedonian Thracians merged with the Romans. We are superior to you in origin ${ }^{29}$.

We are first going to address the issue of the Aromanian armatole discourse, as represented in the excerpts above.

In effect, Nicea uses the pretext of Mucitani's dialogue with Agras to showcase several of the central concepts, which articulate together to form armatole discourse; these are: Macedonian autonomy, multi-national state (and its metaphorical synonym, "Switzerland of the Balkans"), and the "noble" Latin-Thracian ethnic origins of the Aromanian people.

The composite nature of the Aromanian armatole discourse is clearly visible in this enumeration: concepts such as Macedonian autonomy and multinational statehood are clearly borrowed from the TMORO autonomist discourse. After all, it is in the writings of the TMORO-affiliated authors that the idea of a Balkan confederation is put forward ${ }^{30}$ : a multi-national state where all constituent nationalities might live together in peace and cooperation. This project's affinity with Swiss confederalism is not lost on the western observers of the time ${ }^{31}$, which leads to the metaphorical collocation "Switzerland of the Balkans" being used as a synonym for Balkan confederalism.

On the other hand, the idea of Aromanian Latinity, particularly when mobilized as a source of ethnical prestige, is an important feature of the Romanophile discourse.

${ }^{29}$ C. Nicea, op. cit., pp. 9-11 (my translation from the Romanian original); the italics are my inputs; also, my bold letters and underlines.

${ }^{30}$ See Političeski separatizâm, "Pravo", June 7, 1902, quoted in: T. Marinov, op. cit., p. 13.

${ }^{31}$ See V. Bérard, Pro Macedonia, Paris 1904, p. 54. 
What we are in fact looking at here are traces of a creative combination of two discourse types.

The radicalization of the Macedonian crisis places Romanophile Aromanians in a difficult situation ${ }^{32}$. The traumatic events and dire circumstances surrounding and succeeding the Ilinden rebellion force Romanophile Aromanians to rethink their position. Suddenly, they are being attacked by hostile bands of Greek antartes. They must take up arms. However, the pro-Romanian discourse, within which they occupy subject positions, does not provide them with any kind of conceptual frames or subject positions for direct armed activity.

The solution to this predicament comes in the form of a new, adaptive discourse formulation: the armatoles combine elements of two discourse types; they merge elements of a cultural identity discourse type (their "native" Romanophile discourse, to be precise) with conceptual components belonging to a revolutionary political project (the TMORO autonomist discourse).

The reasons for this transformation of Romanophile Aromanian discourse are given clear expression in the reported conversation between Agras and Mucitani.

Just before his execution, Agras taunts Mucitani, saying that Romania will never be truly willing or able to substantially support Macedonian Aromanians on account of its long-term political goals steering it away from the Balkans. Mucitani responds as follows:

- We know that Romania can't help in any way. Romania has its great goals, others than those of Macedonian Romanians. This is precisely why we are opting for Macedonian autonomy, that is to say we are taking our fate into our own hands. We ask nothing of Romania. It is our homeland, we wish it all the best, but we do not ask for its help, we don't want men and weapons, the way Greece goes about things, organizing (armed) bands on its territory and then sending them across the border ${ }^{33}$.

It is plain to see that the Aromanian armatoles are fully aware of Romania's incapacity to provide them with aid. We can now see that this incapacity stems, at least partially, from the insufficiency of the purely cultural

${ }^{32}$ Romania's refusal to sanction military activity (let alone support such action!) placed the Romanophile Aromanians in a very difficult position, effectively leaving them completely open to aggression; as the violence in Macedonia escalated, many Romanophiles ended up losing their lives and/or livelihoods, most often at the hands of Greeks and grecomaniac Aromanians. Romanophile schoolteachers were most particularly targeted as they were seen to be agents of Romanian propaganda; see S. Ţovaru, Problema şcoalelor româneşti din Balcani, Bucureşti 1934, p. 63.

${ }^{33}$ C. Nicea, op. cit., p. 13 (my translation from Romanian), the italics are my inputs. 
program expounded by Romanophile discourse; its lack of clear political goals concerning Macedonian Aromanians ${ }^{34}$ cripples the armatoles, severely limiting their capacity to respond to attacks; after all, nobody takes up arms without a clear and noble cause to fight for. If Romania is unable to provide them with such a cause, the armatoles must look elsewhere for motivation: the TMORO's autonomist agenda sports a clear, achievable and desirable goal; one which allows the Aromanian armatoles to "take their fate into their own hands".

The armatoles' combination of the Romanophile and the TMORO discourse is successful and opportune on account of the complementarity of its two constitutive elements: the TMORO discourse provides the armatoles with a political agenda, featuring conceptual frames for direct aggressive action; this compensates for the Romanian discourse's lack of clear political aims. On the other hand, Romanophile discourse provides the armatoles with a firm cultural grounding for their sense of distinct national identity; this precludes any risk of cultural assimilation by the MacedoSlav comitadj bands, with which they interact on a regular basis.

Furthermore, the TMORO discourse is particularly pliable to such recombination: let us recall Sarafov's evocation of a multi-ethnic "Macedonian people", as well as the fact that the TMORO program called for all Macedonians, irrespective of nationality, to join the revolutionary cause and fight for autonomy ${ }^{35}$. If the Aromanians wanted to join the autonomist cause, there was no barrier to their doing so. As far as the TMORO discourse was concerned, they were already part of the "Macedonian people".

We now possess some understanding of how the Aromanian armatoles and Slav comitadji worked together; and, more importantly, we have gained some insight as to why such cooperation took place, and what circumstances made it possible.

${ }^{34}$ The main thrust of Romania's intervention in the region was towards securing the use of the Romanian language in Aromanian schools and churches. However, the ultimate political goal underlying these cultural aims remains, to this day, rather unclear. Romania did not have a common border with Macedonian lands and, therefore, any territorial claims upon Macedonia were a priori out of the question. Furthermore, the great demographical dispersion of the Aromanian population, coupled with its relatively small number, make of it a particularly ill-suited basis for territorial claims.

${ }^{35}$ As already noted in a previous footnote, the official statutes of the TMORO granted the right of membership to any "Macedonian or Adrianopolitan", while calling for the unification of all "unsatisfied elements", their "nationality" (narodnost) notwithstanding; see T. Marinov, op. cit., pp. 8-9. 
This leaves one more issue open for investigation: namely, that of how the Aromanian armatoles saw themselves. Or, to put it in the terms of Fairclough's theoretical framework, how the subject position of Aromanian armatole was configured within the confines of the new armatole discourse, which we have been discussing.

THE AROMANIAN ARMATOLE: CONSTRUCTING A SUBJECT POSITION

Let us begin our inquiry into the armatole subject position by looking at the basic grammatical structure of some of the simple sentences used by Nicea in the process of narrating events.

We notice that in their overwhelming majority they are classic declarative sentences expressing action processes. The basic structure of declaratives is Subject-Verb-Object (or SVO, for short). Here are a few examples of such sentences taken from Nicea's text:

\section{[...] we (S) shot (V) 15 Greeks $(\mathrm{O})^{36}$.}

We $(\mathrm{S})$ arrested $(\mathrm{V})$ four more Greeks $(\mathrm{O})[\ldots]$ and we $(\mathrm{S})$ shot $(\mathrm{V})$ them all $(\mathrm{O})^{37}$.

We $(\mathrm{S})$ seized $(\mathrm{V})$ them $(\mathrm{O})$ and we $(\mathrm{S})$ shot $(\mathrm{V})$ them $(\mathrm{O})^{38}$.

We (S) killed (V) two Greeks (O) ${ }^{39}$.

As one might notice, these examples were not chosen randomly. These sentences are all unequivocal assertions of the armatoles performing terrible deeds: murdering people. We have chosen such grim examples because what interests us is the issue of responsibility.

Fairclough points out that whenever some morally questionable act is recounted in a text, if the writer favors the perpetrator, he will often tend to conceal agency ${ }^{40}$ - that is, avoid explicitly mentioning the doer of the deed. In such cases, sentences are often given agentless passive forms ${ }^{41}$; this presents the objectionable deed in the guise of an agentless event, instead of a purposeful action.

For instance, any of the above sentences could have just as well been given an agentless passive form; all that one would have to do is eliminate the active subject, and turn the object $(\mathrm{O})$ into the passive subject $(\mathrm{S})$ of the sentence. Like so:

\footnotetext{
${ }^{36}$ C. Nicea, op. cit., p. 16 (my translation from Romanian).

${ }^{37}$ Ibidem.

${ }^{38}$ Ibidem.

${ }^{39}$ Ibidem.

${ }^{40}$ N. Fairclough, Language and Power, p. 104.

${ }^{41}$ Ibidem, p. 104.
} 
15 Greeks (S) were shot (V).

Four more Greeks (S) were arrested $(\mathrm{V})$ and they $(\mathrm{S})$ were all shot $(\mathrm{V})$. Two Greeks (S) were killed (V).

Etc.

The fact that Nicea very rarely uses passive form in his accounts of killings performed by his tcheta and himself shows an unsettling, although complete, willingness to accept full responsibility for all those terrible deeds.

Furthermore, no attempt is made to mitigate the gravity of the deed; such an effect could easily have been achieved by opting to use some gentler euphemisms ${ }^{42}$ en lieu of blunt, direct verbs such as "shoot", "kill", "seize" or "arrest". For instance, one might choose to say:

We laid low 15 Greeks.

Or:

We took four Greeks into custody and put them all out of their misery. Etc.

Yet Cola Nicea uses no such clever devices. He states the facts bluntly and unequivocally. It is very clear that the author makes no excuses for his own and his comrades' acts. Which amounts to saying that they, in fact, felt justified in taking such violent, drastic actions.

This hypothesis is corroborated by Nicea's profuse use of words belonging to a classification scheme ${ }^{43}$ of entitlement and authority. In effect, Nicea has his fellow armatoles performing official speech acts ${ }^{44}$, such as giving orders, or officiously sentencing people to death; these speech acts are accompanied by the performing of actual authoritative actions, such as punishing wrongdoings and executing their enemies.

The use of verbs such as "to punish", to (give an) "order", "to execute" (en lieu of the non-judicial version "to kill"), the employment, in one particular instance, of judicial courtroom vocabulary and procedure (the counts of indictment are read, then the sentence is pronounced: "For all these crimes [...], you are sentenced to death" $\left.{ }^{\prime 4}\right)$, all indicate the presence of a sense of entitlement - specifically, an entitlement to perform justice.

${ }^{42}$ For more on the relevance of euphemism use in discourse analysis, see N. Fairclough, Language and Power, pp. 97-98.

${ }^{43}$ Classification schemes are groups of word associations, which imply a certain ideologically specific way of looking at reality; specific classification schemes belong to specific discourse types; see N. Fairclough, Language and Power, pp. 95-97.

${ }^{44} \mathrm{~A}$ speech act is an utterance through the very speaking, of which an action is performed; often, although not always, this is an official, institutional action, such as marrying a couple, via the priest saying "I pronounce you man and wife", or a judge sentencing a criminal by saying "I sentence you..."; for the fundamentals of speech act theory, see J. L. Austin, How to Do Things with Words, Oxford 1971.

${ }^{45}$ C. Nicea, op. cit., p. 12 (my translation from Romanian). 
Nicea's text offers clues as to the source of this sense of entitlement: it seems that it has its roots in the logics of justified vengeance. In fact, on several occasions, the judicial principle of the law of talion is more or less directly referred to:

Since the antartes were killing any Romanian they met on the open road, we decided to apply the law of talion: for one Romanian slain, we would kill two Greeks ${ }^{46}$.

The Greek shot while he was tilling the field, we wrote on the note attached to his chest, was executed as reprisal for a 12-year-old boy, the son of the Romanian Adamaca from Xirolivad, who had been shot by the Greeks ${ }^{47}$.

Since the Greeks had killed in the village of Doliani the Romanian Gherase, an old man, together with his daughter, while they were hoeing corn, while on our way to Cernova, having encountered two Greeks who were hauling timber to town, we shot them both, together with their mules. Therefore, an eye for an eye, a tooth for a tooth ${ }^{48}$.

The quotations we have given here offer us an insight into the reasons for which the armatoles took violent action, into the thinking underlying their killings. Nicea's text implies that rather than acting violently, the armatoles were mostly reacting - reacting to crimes against members of their community, to be more exact. In a context where the Ottoman authorities are no longer able (and probably, for the most part, unwilling ${ }^{49}$ ) to insure the rule of law and the safety of the Macedonian population, the Aromanian armatoles feel entitled to take justice into their own hands: the Greek attacks upon the Aromanian populace in particular call for proportional reprisals.

Here, we believe to have seized upon an important feature of the armatole subject position: when they are not participating in large-scale operations together with their TMORO allies, the armatoles act as agents of

\footnotetext{
${ }^{46}$ Ibidem, p. 15.

${ }^{47}$ Ibidem, p. 17.

${ }^{48} \mathrm{Ibidem}, \mathrm{p} .18$.
}

${ }^{49}$ The $3^{\text {rd }}$ article of the Mürszteg program - a program of political reforms pushed on the Ottomans by the other great powers in October 1903 - stipulated that, in the aftermath of the region's eventual pacification, Macedonia was to be divided into (more or less) ethnically homogenous sectors; since such administrative division was conducive to future partition of Macedonia between the Balkan states, the Ottomans in fact seem to have had a vested interest in the perpetuation of the Macedonian crisis: as long as Macedonia was in chaos, it remained Ottoman territory; indeed, some contemporary western observers note that the Ottomans' actions in Macedonia are more conducive to fanning the flames of conflict than to appeasing it; see V. Bérard, La révolution turque, Paris 1909, pp. 205-206, 225-226. 
vigilante justice. They are avengers of crimes done against the Aromanian community.

However, the vocabulary of judicial entitlement used by Nicea could also have another, less obvious, source. According to oral historical tradition, in 1537 the Sultan Suleiman I organized Epirus, Etolia, Accarnania, Thessaly and Macedonia into 15 military districts, wherein the local inhabitants (Aromanians, Greeks, Albanians and Slavs) had the obligation of guarding the mountain passes and preserving public order. In exchange for these services, the locals were endowed with fiscal privileges and with a high degree of self-governance ${ }^{50}$. The leaders of these communities were called captains (kapitanos or kapetanios), and the armed men under their command bore the name of palikares or armatoli ${ }^{51}$.

Given the fact that the Macedonian Aromanians seem to have preserved these traditional rights and obligations right up until the $19^{\text {th }}$ century ${ }^{52}$, it seems entirely likely that early $20^{\text {th }}$ century Aromanians would have still harbored a vivid memory of their defunct privileges (implying the right to bear arms and maintain social order, among other things). The use of the name armatole to designate the members of the modern Aromanian armed militias certainly seems to confirm this hypothesis.

What we are suggesting is that Nicea's use of terms belonging to the classification scheme of entitlement and authority may, in fact, be a textual trace indicating the re-activation of the discourse of traditional local Aromanian authority. The fact that such a discourse would seem to be acting in the background, through implicit assumptions of entitlement rather than being explicitly expressed, only testifies to its ideological efficiency ${ }^{53}$.

If the hypothesis we are advancing is correct, this would mean that the discourse and subject positions of the medieval armatole were woven into the discourse and subject position of the modern Aromanian armatole, in effect constituting their invisible, ideological foundation. This hypothesis bears further investigation - a conclusive answer cannot be obtained on the basis of a single text. Unfortunately, Nicea's account is, to date, our only first-hand testimony of an actual Aromanian armatole. It is, therefore,

${ }^{50}$ M. Cazacu, Vlahii din Balcanii Occidentali (Serbia, Croaţia, Albania, etc.) Pax Ottomanica (secolele al XV-lea-al XVII-lea), in: Aromânii: istorie, limbă, destin, ed. N. Djuvara, Bucureşti 2012, p. 111.

${ }^{51}$ Ibidem, p. 111.

${ }^{52}$ François Charles Hugues Laurent Pouqueville quoted in ibidem, p. 111.

${ }^{53}$ According to Norman Fairclough, a discourse functions ideologically when it supports existing relations of power (or affirms new power relations); the more an ideology works through implicit assumptions and presuppositions, that is to say, the better hidden its inner mechanisms are, the more effective that ideology is; see N. Fairclough, Language and Power, pp. 64-90. 
our only unmediated "window" into armatole discourse; in the absence of intertextuality, verifying and corroborating Cola Nicea's discourse constructions seems near impossible. We shall address this problem further in the conclusions to the present study.

For the moment, however, let us proceed with our analysis of the armatole subject position. Cola Nicea uses the reported conversation between Gheorghe Mucitani and his Greek captive, Telos Agras, to showcase the nature of the subject position, which he and his comrades in arms occupied, within armatole discourse. Let us reexamine the dialogue fragment that we reproduced above.

At one point, Mucitani accuses Agras of lacking chivalry. As we shall see, the use of the word "chivalry" here is crucial. It activates, within the reader's MR (Members' Resources ${ }^{54}$ ) a script for chivalrous behavior.

Fairclough defines scripts as a type of mental representation, which pertains to how specific types of subjects behave and relate to each other in various social contexts ${ }^{55}$. Our MR contains scripts for all kinds of subject types. For instance, we have a certain script for a mother's behavior, another script for a policeman, etc.

In our case, the use of the word "chivalry" activates in our MR the script for the medieval knight: always behaving honorably and justly, being merciful and kind, etc. This script is mobilized by readers as an interpretative procedure, which in turn guides the reader's construal of the narrated events in a certain, very specific, direction.

Let us elaborate. If we examine the beginning of the discussion between Mucitani and Agras, it immediately becomes apparent that it belongs to the discourse type of interrogation. Mucitani's questions are curt and to the point ("What is your name?", "Where are you from?"), and Agras's answers are correspondingly succinct and on topic. However, as the interrogation progresses, it begins to evolve into something resembling a casual conversation. This is most unusual, as it breaks all established conventions for how an interrogation is supposed to unfold. Usually, if the weaker participant (the interrogated subject) ever drifts off-topic or gives information not solicited, the more powerful participant (the interrogator) constrains the other party's contributions, forcing them to be succinct and on point ${ }^{56}$.

\footnotetext{
${ }^{54}$ According to N. Fairclough, Members' Resources, or MR, represent the eclectic body of information that people are endowed with through the process of socialization: all the things that people learn through functioning in society. This includes: knowledge of language, representations of the natural and social worlds they inhabit, beliefs, values, assumptions, etc.; see N. Fairclough, Language and Power, p. 20.

${ }^{55}$ See N. Fairclough, Language and Power, pp. 131-133.

${ }^{56}$ See ibidem, pp. 113-114.
} 
How are we then to interpret the fact that in the case of our interrogation this does not happen? What are we to make of the fact that Mucitani allows Agras to digress, allowing the interaction to drift into a casual conversation of the merits and faults of Romanian and Greek national ideologies?

The one interpretative key the reader possesses lies in the concept of chivalry: if Mucitani accuses Agras of being unchivalrous, than, by implication, Mucitani himself is to be construed as a person to whom chivalrous behavior is important. In this reading then, Mucitani's allowing Agras to digress is a sign of generosity. Even though he is the more powerful participant, the armatole does not wish to oppress his captive; he therefore magnanimously allows him to speak his piece and a debate ensues. The fact that Agras is permitted to engage in this debate as an equal participant is a further mark of noble generosity on Mucitani's part.

As we read through the reported conversation between Mucitani and Agras, we are provided with further clues which elicit interpretations drawn from the script for chivalrous behavior. For instance, at one point Mucitani tells Agras about the armatoles' treatment of some captured Greek antartes:

- The tcheta of Mitrea Vlahu captured at Leahova four Greek antartes having come from Crete. Taking pity on them, for they were young, he had them swear on the Holy Gospel that they would return to Greece. After he let them go, within two months he captured them again $[\ldots]$, and, of course, this time he killed them ${ }^{57}$.

Showing mercy towards a captured foe is a decidedly chivalrous behavior. Then again, so is punishing the dishonorable act of breaking one's given oath. Another example:

We gave the two prisoners equal portions of food and brandy, same as the ones we received. We never starved them ${ }^{58}$.

Or:

We let them talk (to each other). We never resorted to tortures, as the Greek bands did. We chose the lightest, painless punishment: hanging 59 .

The humane treatment of their prisoners is to be construed as a sign of the armatoles' honor, a mark of a noble heart; this is because rebuk-

${ }^{57}$ C. Nicea, op. cit., p. 11 (my translation from Romanian).

${ }^{58}$ Ibidem, p. 12

${ }^{59}$ Ibidem, p. 14 (my translation from Romanian), the italics are my input. 
ing unnecessary cruelty towards one's prisoners is a typically chivalrous behavior.

If we look at the fragments that we just quoted from a literary perspective, we notice that Cola Nicea is, in fact, using a literary device: indirect characterization. That is to say, the armatoles are characterized not by explicitly saying that they are honorable, merciful, chivalrous, etc., but indirectly, through their deeds, through the way they act.

In the narrative section leading up to Agras' execution, Nicea further develops this literary device, by resorting to cross-characterization. That is to say, Agras, on the one hand, and the armatoles putting him to death, on the other, are characterized via the way in which they reciprocally interact, via their mutual attitudes.

In one passage we see the armatoles admiring Agras' proud and stoic attitude in the face of imminent death. And conversely, their respectful treatment of the condemned is meant as a reflection of the armatoles' own nobility of heart:

Agras had become calm, he was even defying death. He truly believed in the ideal, which he had resolved to fight for. As far as he was concerned, he was sincere, he had believed in an ideal, he had been defeated, but he insisted on dying as a man of honor. His attitude in the face of death, full of dignity, deserved our esteem. And we respected him. He was never tortured, or cursed at, or mocked ${ }^{60}$.

\section{Another example:}

We never used base means of coercion, for according to his chivalrous fashion, Agras wouldn't have said a word. When we had brandy, we gave some to him. [...] While Mingas was crying, falling apart, Agras remained dignified, chivalrously. We never offended him. In his fashion, we deemed him a fighter in the service of an ideal, in no way a thug ${ }^{61}$.

Notice that in the second fragment, the attribute "chivalrous" is twice applied to Agras. By means of cross-characterization, this reflects upon the armatoles' own noble nature: by recognizing Agras' chivalrous character, the armatoles themselves prove to be chivalrous: "it takes one to know one", as the saying goes.

Interestingly, in using cross-characterization to construct the subject position of the armatole, Cola Nicea creates an unexpected by-product. Notice the wealth of adjectives being applied to Agras: he is sincere, dignified, deserving of esteem, chivalrous, an idealistic fighter. What we are in fact seeing here is a representation of the ideal-typical ${ }^{62}$ Greek antart.

${ }^{60}$ Ibidem, p. 13 (my translation from Romanian).

${ }^{61}$ Ibidem, p. 14.

${ }^{62}$ We are using the concept of ideal-type in the Weberian sense. 
However misguided his cause may be, Agras, just as all antartes, is fighting for an ideal, in which he strongly and sincerely believes. And this affords him the respect of his enemies.

The ideal-typical image of the Greek antart shares many of the basic qualities implicit in the Aromanian armatole subject position. However, one crucial trait separates the two: as opposed to the armatoles' clemency, the Greek antart is shown to be possessed of great cruelty. There are several instances within the text where reference is made to the antartes' ruthless behavior. We shall give but one example, a passage attributed to Agras himself:

Agras said to Mingas: "An antart is not allowed to cry. Remember what plans we were making should one of our enemies have fallen into our hands, especially the teacher Gheorghe Celea and that Lycantropos (wolf man) Adam Gulea, how we would have impaled them or blinded them, reiterating on a smaller scale the deed of the emperor Basil the Bulgar Slayer, then would have sent them back to their villages blind, to spread terror among the Romanians" ${ }^{\prime 63}$.

\section{CONCLUSIONS}

In the present paper, we have applied elements of N. Fairclough's method of discourse analysis to the Memoirs of Cola Nicea, to date the only first-hand account of the actions, convictions and beliefs of the Aromanian armatole fighting in early $20^{\text {th }}$ century Macedonia. Let us sum up what we have achieved.

We have explored Cola Nicea's use of the ethnonym "Bulgarian" and have concluded that he uses it mainly in reference to the TMORO agents, that is, to Macedo-Slavs fighting for Macedonian autonomy.

We have then delved into the issue of the Aromanian armatoles' collaboration with the TMORO. We have attempted to show how this collaboration is expounded in Nicea's Memoirs. Furthermore, we have found that the Romanophile discourse's inadequacy in dealing with the radicalization of the Macedonian crisis prompted the Romanophile Aromanians to creatively combine the Romanian and TMORO discourse. This new combination of discourse types allowed the armatoles to take up arms and ally themselves with the TMORO, while still preserving a strong sense of cultural identity and national individuality.

Finally, we have looked at the ingenious and diverse devices, which Cola Nicea uses to construct a subject position for the Aromanian arma-

${ }^{63}$ C. Nicea, op. cit., p. 14 (my translation from Romanian). 
tole. This subject position, as expressed in Nicea's text, can be summarized thus: the armatole performs acts of vigilante justice, by taking vengeance upon those who have wronged the Aromanian community; however, he is not prone to violent excesses - he is ready to show mercy where mercy is warranted and acts in a just and even-handed manner, even towards his enemies. His behavior is never needlessly cruel and the punishments he administers are always proportional to the crime.

We are now left with just one more issue to discuss: that of Cola Nicea's creditability. Let us emphasize that we are not speaking of his creditability as a historical source. That issue is entirely beyond the scope of the present paper. What interests us is his creditability as a source for the identity discourse of the Aromanian armatoles.

The Memoirs do paint a compelling picture of how the armatoles perceived themselves, their surroundings and their actions, and how they interacted with other groups. However, these representations are notoriously hard to corroborate since Nicea's account is the only direct source we have on the subject (if not the only source). We are, in a sense, constrained to take him at his word. Furthermore, given that the memoirs were written down many decades after the fact, Nicea's interpretations of motivations and narrated events may have been colored by the many political and social changes, which occurred "in the meantime". As such, the text that he provides us with should be regarded as a secondary source.

There is, however, a silver lining. The fact that the Memoirs were put to paper so many years after the fact also means that many of the ideological pressures, which would have weighed upon the creator of such a text a hundred years ago (that is, in the immediate aftermath of the recounted events) are in this case simply not an issue. From this perspective, Nicea is free to speak the truth of things the way he saw them. There is, of course, no escaping the author's subjectivity. He can perhaps be suspected of sweetening some of the more unpalatable aspects of armatole activity (though one certainly does not get that impression upon reading the text); or, perhaps, of remembering certain events inexactly. However, it seems unlikely that Nicea could be suspected of purposefully and blatantly lying.

All in all, we would contend that Nicea's account of the Aromanian armatole discourse does deserve the attention of researchers in the field of Aromanian Studies - provided, of course, that one takes into account the complex circumstances of the text's creation, and uses complementary sources to corroborate the recounted events, while also placing the said events in the appropriate historical context. 


\section{BIBLIOGRAPHY}

Austin J. L., How to Do Things with Words, Oxford 1971.

Bérard V., La révolution turque, Paris 1909.

Bérard V., Pro Macedonia, Paris 1904.

Castellan G., Histoire des Balkans XIVe-XXe siècle, Fayard 1991.

Cazacu M., Vlahii din Balcanii Occidentali (Serbia, Croaţia, Albania, etc.) Pax Ottomanica (secolele al XV-lea-al XVII-lea), in: Aromânii: istorie, limbă, destin, ed. N. Djuvara, Bucureşti 2012.

Dakin D., The Greek Struggle in Macedonia 1897-1913, Thessaloniki 1966.

Fairclough N., Critical Discourse Analysis, in: The Routledge Handbook of Discourse Analysis, ed. J. P. Gee, M. Handford, London and New York 2012.

Fairclough N., Language and Power, $2^{\text {nd }}$ edition, London, New York 2001.

Howarth D., Stavrakakis Y., Introducing Discourse Theory and Political Analysis in: Discourse Theory and Political Analysis: Identities, Hegemonies and Social Change, ed. D. Howarth, A. J. Norval, Y. Stavrakakis, Manchester and New York 2000.

Jelavich B., Istoria Balcanilor, vol. 2, Iaşi 2000.

Katardžiev I., Nekoi prašanja za ustavite i pravilnicite na VMRO do Ilindenskoto vostanie, "Glasnik ná Institutot za nacionálna istorija" 1961, 1.

Marinov T., We, the Macedonians: The Paths of Macedonian Supra-Nationalism (1878-1912) in: We, the People: Politics of National Peculiarity in Southeastern Europe, ed. D. Mishkova, Budapest 2009, http://www.ceeol.com/aspx/getdocument.aspxlogid=5\&id=5db4b51192bd4f7a85e7699046929d54 [accessed on: 13 November 2015].

Nicea C., Memorii [Memoirs], document originally published in: Scara - Revistă de oceanografie ortodoxă, Bucureşti: Treapta 7, 2001. Digitized by Predania Publishing House, http://www.proiectavdhela.ro/pdf/cola_nicea_memoriile.pdf [accessed on: 12 November 2015].

Nistor I., "Problema aromână" în raporturile României cu statele balcanice (1903-1913) Iaşi 2009.

Peyfuss M. D., Aromânii în era naţionalismelor balcanice in: Aromânii: istorie, limbă, destin ed. N. Djuvara, Bucureşti 2012.

Sériot P., Ethnos et demos: la construction discursive de l'identité collective [English Translation] “Langage et société" 1997, 79. Analyse discursive et engagement: autour de l'Europe de l'Est.

Trifon N., Les Aroumains, un peuple qui s'en va, La Bussière 2005.

Ţovaru S., Problema şcoalelor româneşti din Balcani, Bucureşti 1934.

Widdowson, H. G. Discourse Analysis, Oxford 2007.

Wodak R., The Discourse of Politics in Action: Politics as Usual, Palgrave Macmillan 2011.

\section{ABSTRACT}

The article begins with a general presentation of Cola Nicea's Memoirs - the document which is to be investigated using methods drawn from Critical Discource Analysis. The paper continues with a study of the ethnonyms used by Nicea throughout his account, which leads into a discussion of Macedonian Slav and Macedonian Aromanian identities at the turn of the $20^{\text {th }}$ century. Then it discusses the forms of - and reasons for - cooperation between the Aromanian armatoles and TMORO comitadji, as reflected in Nicea's text. The information contained in this source-material proves that, philoromanian discourse proving 
ill-equipped to deal with the radicalization of the Macedonian crisis, Romanophile Aromanians adapt by creatively combining the latter discourse with the TMORO political agenda. Finally, the paper refers to the diverse textual and meta-textual devices which come into play in Cola Nicea's iteration of the Aromanian armatole subject position.

Key words: identity, discourse, subject position

\section{ABOUT AUTHOR}

Vladimir Crețulescu - an independent researcher with a PhD in History and Political Science from the universities of Bucharest and Bordeaux, respectively (2016). He also possesses a Master degree in Medieval Studies (2010) and a Bachelor degree in Art History (2008) from the University of Bucharest. He has published several articles on nationalism and on identity politics in the Balkans. His current main research interest is the discursive construction of Aromanian national identities. 